\title{
Cultures unfolding: experiences of Chinese-Hungarian mixed couples in Hungary
}

\author{
Nóra Kovács \\ Hungarian Academy of Sciences, Budapest, Hungary
}

BACKGROUND

The research outlined in this paper focuses on a subfield related to Chinese migrants' integration in Hungary: Chinese-Hungarian mixed partner relationships. I present some findings of an anthropological study on Chinese-Hungarian couples in Hungary, although other localities may also be involved in some of these couples' lives.

\section{PARTICIPANTS AND PROCEDURE}

Based on interviews conducted with members of Chinese-Hungarian married, cohabiting and dating, separated or divorced couples, and on data gathered through predominantly online fieldwork, this research explores notions and values that are at play in shaping the dynamics of these relations.

\section{RESULTS}

The sample of thirty-seven couples features two characteristically different types of relationships: those referred to as "student love", and the relationships of "typical" Chinese migrants with Hungarians. The former tend to be much more successful and persistent in time, with two cases of divorce or separation out of sixteen, whereas the latter are considerably less persistent, with eight cases of divorce or separation and two cases of crises out of thirteen bonds. Another notable finding is that Chinese-Hungarian marriages are much more persistent in time if the Chinese partner is female.

\section{CONCLUSIONS}

The paper consists of the following consecutive parts: an introduction to the Chinese migrant context and inter-ethnic partner relations in Hungary; a review of relevant literature; presentation of research methods and fieldwork; presentation and discussion of the research sample; presentation of some results from the interviews; and conclusions.

\section{KEY WORDS}

mixed partnerships; Chinese-Hungarian couples; intermarriage; migrant marriage; migration anthropology; Chinese-Hungarian relationship types

Corresponding Author - Nóra Kovács, Ph.D., Centre for Social Sciences, 1014 Budapest, Országház utca 30., Hungary, e-mail: kovacs.nora@tk.mta.hu

Authors' Contribution - A: Study design · B: Data collection · C: Statistical analysis · D: Data interpretation ·

E: Manuscript preparation · F: Literature search · G: Funds collection

TO CITE THIS ARTICLE - Kovács, N. (2015). Cultures unfolding: experiences of Chinese-Hungarian mixed couples

in Hungary. Current Issues in Personality Psychology, 3(4), 254-264.

RECEIVED 06.05.2015 - REVIEWED 21.07.2015 • ACCEPTED 13.09.2015 · PUBLISHED 28.09.2015 


\section{BACKGROUND}

Non-Hungarian international migration to Hungary started shortly after the shift of regimes in 1989. According to a recent study on migration to Hungary, in January 2013 there were 141 thousand foreign citizens and 423 thousand foreign-born persons living in Hungary out of its roughly ten million inhabitants, and this population accounts for $4.3 \%$ of the total population (Kováts, 2014). Most of the migrants arriving and settling in Hungary are ethnic nationals from neighbouring countries forming a large invisible group (Kováts, 2014).

The Chinese form the largest visible minority group in Hungary. New visa regulations after the shift of regimes favoured their arrival: Chinese citizens needed no visa to enter Hungary between 1989 and 1992. Their number reached over forty thousand by the late 1990s, with roughly as many men as women among them. A large proportion of Chinese migrants to Hungary were young adults in their twenties or early thirties, many of whom arrived through chain migration. The first reports on Chinese migrants arriving during the 1990s describe them as relatively educated, self-sufficient people equipped with the social capital of transnational networks. Most of them dedicated themselves to shoes and clothes retail and wholesale in Budapest and in the countryside; however, a large majority has lived in Budapest. Besides commercial units, shops, markets, food stands and restaurants, dozens of immigrant Chinese organisations and institutions have been formed since the early 1990s.

Probably due to the changing legal and economic environment, many of them have left since. The 2011 national census registered somewhat less than nine thousand Chinese citizens living in Hungary, while experts in the field estimate this figure to be no higher than fifteen thousand. The Chinese in Hungary do not represent a specific Chinese geographical region although there is a marked group from the South East provinces of Zhejiang and Fujian whose members work in restaurants. Their relative proportion within the Chinese diaspora in Hungary has risen recently (Nyíri, 2010a). The business model of Chinese entrepreneurs has, for many of them, changed since the early 1990s from small-scale trade to transnational network-based wholesale, often covering areas in neighbouring European countries as well (Várhalmi, 2013).

Bearing in mind potential Chinese migrant partners for members of the Hungarian host society of the early 1990s, we could draw the profile of a "typical" Chinese migrant: this person would be around 25 of either sex, could come from any part of mainland China, may have had formal education including a college degree, but would pursue commercial activities and would invest limited efforts in learning Hungarian.
Although treated as an established integration indicator ${ }^{1}$, researchers tackling the problem of integration of Chinese migrants into Hungarian society have not addressed partner relationships specifically, considering that the existence of Chinese-Hungarian mixed marriages is not typical. As Nyíri stated, "marriages with Hungarians and interethnic partner relations are more common in the countryside, but even there they are infrequent” (Nyíri, 2010b, p. 153). It seems that this was not generated by endogamous norms expressed by members of the Chinese diaspora. "Exogamy is allowed. Some Chinese men, especially small town business owners, live together with Hungarian women, and some mixed marriages do exist" (Nyíri, 2006, p. 44). As to the partner choice of the second generation of Chinese migrants, "parents usually have no problem with their sons and daughters dating Hungarians; they do not interfere with their partner choice" (Nyíri, 2006, p. 44). So why are there few cases of interethnic couples? Preliminary fieldwork suggested that there were Chinese-Hungarian mixed couples, although their number was not significant compared to the size of the Chinese population in Hungary.

I would like to draw the attention to a concept applied to the Chinese population in Hungary by Nyíri, an anthropologist who studied the Chinese diaspora in Hungary during the 1990s. He interpreted Chinese tradesmen's role played in Hungarian society as that of a "middleman minority", a concept introduced by Jonathan Turner and Edna Bonacich in 1980 (cited by Nyíri, 2010a). The concept of middleman minority refers to migrants who, based on cross border ethnic networks, occupy institutionalised positions in certain well-defined areas of the economy between the highest and the lowest strata of society, while they stay outside the social hierarchy since they are foreigners. This notion could possibly have a bearing on the formation of partner relationships between Chinese migrants and members of the host society ${ }^{2}$.

\section{HOW TO APPROACH THE PHENOMENON OF CHINESE-HUNGARIAN MIXED PARTNER RELATIONSHIPS?}

Ethnically mixed relations between Chinese migrants and members of Hungarian society relate to a wide range of issues such as marriage-related social mobility into the host society, and also transnationality.

Demography, sociology, social anthropology and migration research have addressed several research problems that are relevant to the study of Chinese-Hungarian mixed relationships. Three branches of literature have proved to be particularly helpful in the attempt to approach this phenomenon: articles on intermarriage and works within the immense literature of relationship studies that include 
notions of race, culture, transnationality, and partner satisfaction in their analyses (see for example Hohmann-Marriott \& Amato, 2008; Worner, 2010); migration studies with a focus on mixed marriage as a factor of migrants' integration; and literature on Chinese society, especially about changes in family relations. Although more popular than academic, I have found Chua's views on what she calls Chinese parenting (Chua, 2011, 2014) and the public reaction given to it quite inspirational during the interpretation of data on mixed marriage parenting.

Discussing intermarriage in society, Kalmijn overviews hypotheses on the causes of endogamy and homogamy (marriage between partners close in status) based on empirical and theoretical studies (Kalmijn, 1998). He argues that theories about partner choice provide important clues to the causes of intermarriage. He names three social forces that shape marriage patterns: the preferences of individuals for resources in a partner, the influence of the social group, and the constraints of the marriage market (Kalmijn, 1998). Surveying marriage literature, the author concludes that the multifaceted perspective that has been developed over the years gives sociological theorizing an edge over competing theories of marriage choice such as those developed by psychologists and economists (Kalmijn, 1998). In another piece of research on the risk of divorce in the Netherlands he tests the heterogamy hypothesis, that mixed marriages are more likely to end in divorce than homogamous ones (Kalmijn, de Graaf, \& Janssen, 2005). Taking into consideration nationality and religion, the authors found that the greater the difference between the social groups of the spouses, the greater is the risk of divorce, and that new group boundaries in the Netherlands are more difficult to cross than old ones. A similar line of enquiry is further developed by a comparative study trying to grasp the reasons why and how certain national-origin groups in the US are more likely to intermarry than others (Kalmijn \& van Tubergen, 2010). Among several findings, the authors point out the importance contextual factors, especially that of culture, in explaining endogamy (Kalmijn \& van Tubergen, 2010).

The connection between intermarriage and immigrant integration in Sweden with a special focus on economic integration is analysed by Dribe and Lundh using cross-sectional registry data from 39 immigrant groups (Dribe \& Lundh, 2008). The authors draw attention to several important points. They emphasize differences between immigration patterns and immigrant integration in the US and Europe, which make it difficult to draw conclusions about intermarriage and its impact on immigrant integration in Europe based on studies from the US (Dribe \& Lundh, 2008). They have found that the length of the adaptation period in the host country before marriage is connected with higher intermarriage rates, but the ef- fects are stronger for refugees than for labour immigrants (Dribe \& Lundh, 2008). Their data suggest a negative effect of the relative size of the pool of potential spouses of the same origin in the residential community. They find a strong association between intermarriage with natives and economic integration in terms of employment and income. They emphasize that there are differences between immigrant groups in terms of family culture (family systems, kin relations, marriage customs) and also that these are highly persistent over time (Dribe \& Lundh, 2008).

Sociological attempts have also been made to set up an intermarriage typology. Gaspar studied bi-national partnerships formed by intra-European migrants in Italy and Spain (Gaspar, 2011). Analyzing large-scale data on the motivations of intra-European migrants who moved between 1974 and 2003, she draws attention to the fact that love or affective reasons have become an important migration rationale in addition to economic and life quality ones. Gaspar formulated a threefold typology labelling partnerships love migrant bi-national couples, Eurostars' bi-national couples, and retired migrant bi-national couples (Gaspar, 2011), with the first of the three clearly motivated by "love".

Social scientific research on international migration since the 1990s has provided a new conceptual framework for the study of diasporas, thus setting new directions for it. "Transnational anthropology" started to study simultaneously two or more locations, social networks and discourse and symbol systems affecting migrants' lives. The focus in migration research thus shifted from assimilation models, the melting pot theory, and second generation culture change towards the study of simultaneous economic, family and cultural ties of diasporas with two or more locations or countries (Basch, Glick Schiller, \& Szanton Blanc, 1994). Members of the Chinese diaspora all over the world are commonly associated with a transnational way of life, with simultaneous social, economic, and cultural ties to several locations in different countries. Literature and fieldwork experiences suggest that this form of existence is typical of Chinese migrants in Hungary as well. A migrant's mixed marriage creates a transnational situation per se. To what extent does this apply to the lives of Chinese-Hungarian couples and families with children? How do transnationalism, spatial mobility and simultaneous ties to different places appear in the lives of mixed marriage-based families? Is there a typical connection between the Chinese parent's transnational strategies and the language strategy they use in the family? Do mixed marriage children in Hungary become transnationals themselves?

Western anthropology has expressed a long-time interest in Chinese society and culture. Classical anthropological inquiry has focused on its institutions and on various aspects of the social bonds that 
construct them ${ }^{3}$. Chinese society and its institutions have undergone substantial changes in recent decades. Family and marriage and their transformation in China have been widely studied, and a focus on gender aspects and power relations ${ }^{4}$ has increasingly appeared in the literature for several decades now (see for example Davin, 1976, 1988 on Domenach \& Chang Ming, 1987). Many studies aim at the transformation of Chinese society and family, and their changing values and norms in a globalising world. Representing a different view of their own society, Chinese anthropology has joined Westerns scholars in the attempt to highlight and understand contemporary Chinese social and cultural processes (see Kwokbun, 2013; Stafford, 2013; Davin, 1999; Kleinman, Yan, Jun, Lee, \& Zhang, 2011).

The phenomenon and social consequences of migration and remigration for the sending society have been explored in China and especially in Hong Kong, and elsewhere in South-East Asia. The social effects of marriage migration from different parts of Asia promoted by transnational marriage industries have also been studied widely. Bélanger and Tran have shown how Vietnamese women's marriage migration to Taiwan and South Korea lead to important social transformations including the rise of their own status and that of the other village daughters in their rural sending communities (Bélanger \& Tran, 2011).

By surveying nearly two thousand Chinese married couples about their marital relations and the quality of their marriage, Efron Pimentel provided a vivid picture of Chinese marriages in an urban setting at the end of the 20th century (Efron Pimentel, 2000). "Can a common set of assumptions about the marital relationship be applied to different societies?" is one of her central questions regarding Beijing marriages (Efron Pimentel, 2000, p. 32). She points out that "historically the conjugal bond took a distant second place to intergenerational ties between parents and children, especially sons" (Efron Pimentel, 2000, p. 32). The Chinese patrilineal kinship system, arranged marriages, and virilocal postmarital residence kept conjugal bonds inferior to intergenerational ties. "Marriage was universal and utilitarian, conducted for the purposes of having children and furthering the larger family group" (Efron Pimentel, 2000, p. 33). During the $20^{\text {th }}$ century, however, ideas about marital relations in China have changed greatly. Free-choice marriages appeared. The Communist Party placed most women in paid employment, changed marriage laws, and promoted mutual love and companionship as major criteria in selecting a mate. The Chinese divorce law recognises that a lack of affection between spouses provides grounds for divorce (Efron Pimentel, 2000). Pimentel found that interaction between spouses outside the family was not an important component of marriage quality. Most of the respon- dents in her research had not dated before their marriage. Parental approval seemed to affect marriage quality strongly, and the Chinese couples seemed to share a relatively unromantic vision of love.

How are distance and closeness created and manifested in Chinese-Hungarian partner relationships, and how are they related to the individuals' cultural backgrounds? An important set of questions concerns offspring. What parenting attitudes do Chinese-Hungarian couples tend to adopt? How do everyday practices of living together, language use, childrearing strategies, and attitudes to work in Chinese-Hungarian couples reflect the relative positions of power of different cultural backgrounds within the relationship? How do gender issues influence this picture?

At the beginning of field research in 2013, I conducted an interview with an elderly Chinese man living in Hungary who had been recommended to me as a well-integrated member of the Chinese community and who was considered an intermediary between migrants and hosts by one of his compatriots. He had dedicated his entire professional life to learning and teaching Hungarian as a foreign language and became a university professor of Hungarian at a prestigious university in China. He had spent several long periods in Hungary during the course of his life before finally settling in Budapest. I hoped that he would know mixed couples and could help me to establish contact with them. He talked in Hungarian enthusiastically, and I did my best to tell him that I intended to study Chinese-Hungarian mixed marriages from the point of view of cultural anthropology. He seemed to follow what I was saying, then told me that once he had a failed relationship with a Hungarian woman and that he couldn't help me by providing contacts because he did not have any. I was on my way home from the interview when he telephoned and told me that there he was with his wife sitting next to him and that he thought that they could actually help me. He gave personal data of his wife's nephews, two Chinese men in their thirties who had arrived in Hungary a couple of months before. He named the prestigious Chinese restaurants where they worked as cooks, told me how much they earned per month and added that they were about to get a rise. They would be interested in marrying Hungarian women of their own age or maybe a little older but definitely not divorcees. I told him again that my interest in mixed marriages is not setting them up but studying those that already existed. I found this episode informative on how, in spite of communicating fairly fluently in the same language, the cultural embeddedness of certain concepts, such as "marriage" and "an anthropological study on mixed marriage" in a Chinese-Hungarian context may invite different culturally conditioned associations and drive a conversation onto separate tracks. 


\section{PARTICIPANTS AND PROCEDURE}

\section{SCOPE, RESEARCH METHODS}

Originally, the enquiry presented here was aimed at formalized marriages between Chinese and Hungarian persons living permanently or temporarily in Hungary, but later data on cohabiting and dating, and separated or divorced persons, as well as data from such couples living outside Hungary, were also included. Experiences of failed inter-ethnic relationships can be equally informative of the role of cultural backgrounds within partner relationships. Also, locating and contacting these couples and individuals proved to be a challenging task, with a high rejection rate, while no data relevant to the subject was to be dismissed.

Attempts were made to obtain official data on the possible number of formalized relations, but these records were not kept separately and could not be accessed. Data on Chinese-Hungarian marriages registered in Hungary lay separately in district notaries' record books. Considering Budapest areas with a concentrated Chinese population, the notaries of the $8^{\text {th }}$, the $9^{\text {th }}$ and the $10^{\text {th }}$ districts of Budapest were approached, soliciting Chinese marriage records for the last ten years. One of the notaries refused to provide data, while the other two gave an average of one marriage per year involving one (in some cases two!) Chinese partner(s). It also has to be noted that all the married couples interviewed so far formalized their union outside Hungary.

The data analyzed in this paper was gathered between January 2013 and January 2015. Using informal channels opened up by a three-year-long process of Chinese language learning and also with the help of contacts from my personal network of friends and acquaintances, I tried to identify Chinese-Hungarian inter-ethnic partner relationships and obtained an accidental sample that is not representative of the Chinese population in Hungary in terms of professional activities and education, although quite by chance it turned out to be so in terms of gender and age. Several potential interviewees preferred not to participate in the research, and even some of those who cooperated preferred to avoid certain topics such as the detailed description of their work activities, their economic achievement, or reflections on their sentiments. Although partial, the information gathered through interviews provides Chinese and Hungarian visions of the everyday realities of living in a Chinese Hungarian partner relationship.

Chinese language fluency seems one of the several prerequisites of gathering qualitative data among Chinese migrants in Hungary. I have been learning Chinese for several years but have not reached the fluency to conduct interviews. Thus the interviews were conducted in Hungarian. During the fieldwork period I developed the impression that the interview rejection rate in this particular research has not been influenced by the specific language proposed for use for the interview.

My first interview aimed at mixed marriages took place with a successful wholesale merchant and his second generation son, raised in Hungary, with a university degree in economics. I had asked them to help with this research project by telling me what they knew about Chinese-Hungarian couples and how to contact them. The father arrived with a file case filled with a handwritten list and articles cut from Hungarian Chinese newspapers about Chinese persons with Hungarian spouses. During our meeting in a shopping mall we went through his list entry by entry. He backed up each piece of personal information he gave me with a newspaper cutting that can be publicly accessed by anyone interested. Finally, he asked me not to name him as the source of all the information he provided.

Part of the data comes from interviews conducted with members of couples and with other Chinese and Hungarian persons (e.g. the director of a Chinese-Hungarian bilingual school; ethnic-Hungarian Chinese language professionals) whose professional lives intersect. The interview material was complemented by information from the electronic media, online papers and magazines, television documentaries, and also from online fieldwork that included unprotected information from Facebook.

\section{THE COMPLETE SAMPLE: A LIST OF THIRTY- SEVEN COUPLES}

By January, 2015 I had compiled a list of thirty-seven Chinese-Hungarian mixed partner relationships that I managed to identify. I interviewed members of seven. It was only in one case that both partners were willing to participate. More couples were contacted from the list and I obtained some information from them regarding their relationship without actually conducting an interview. Out of the thirty other relations where a complete interview has not been conducted, I have uneven and fragmented but rich qualitative information on eighteen couples from third parties and from the internet; and uneven, fragmented and scarce information on the remaining twelve relationships.

There is very rich material available on the internet about certain couples and their families. The Chinese-Hungarian bilingual school is in the constant focus of the electronic and the print media. Numerous mixed marriage children attend the school and several parents have talked about their lives and their reasons for sending their children there in television documentaries ${ }^{5}$. Certain mixed marriage children have drawn media attention due to their sports results or as Asian beauty contestants. 
I tried to obtain the following basic pieces of information of all the couples: gender of the Chinese partner, migrant generation (first or second), living together or not and country of residence, approximate birthdates, immigration dates and beginning (and end) dates of the relationship, country of residence (China, Hungary, other). I also tried to find out on what level they speak their partner's mother tongue, if they do, and whether they have any children together and what language skills their children have acquired. Wherever I had the information I noted whether the relationship was legally a marriage and whether either of the partners had completed university education.

The accidental sample includes people from very different age groups ranging from twenty-seven to eighty-three, and the relationships are in different phases. I encountered cases of marriage, dating, long distance or visiting relationship, separation, and divorce. Lacking direct information from the parties involved, I relied on evaluation of people from their social environment. Migration literature commonly assumes that the time spent in the host society is an important factor when it comes to the interpretation of migrants' integration, including the formation of partner relationships and intermarriage, into the host society ${ }^{6}$.

Talking about mixed couples with Hungarians involved with Chinese migrants (mainly Chinese language teachers and interpreters and long-time practitioners of tai chi and kung fu), I encountered two contradictory stereotypes concerning the typical gender composition of such a relationship. Some stated that it is exclusively Chinese women entering a relationship with Hungarian men, while others said just the opposite. In the sample of thirty-seven relationships, there happen to be eighteen Chinese men and nineteen Chinese women.

The available information suggests an interesting thing: there seems to be an important difference in how "persistent in time" a relationship is depending on whether the Chinese partner is male or female. The "non-divorce" or "not separated" rate is fifty-three percent in the case of Chinese men and eighty-seven percent in the case of Chinese women (divorce/non-divorce data are missing in five cases).

Bearing in mind the demographic characteristics and professional activities of the Chinese migrant population in Hungary of the early 1990s, it would be most interesting to trace their integration in Hungary through inter-ethnic partner relationships and mixed families. Out of the thirty-seven cases there are thirteen Chinese migrants who can be considered strictly "typical" regarding the date and purpose of their arrival (early 1990s, making business during the transition to a market economy) and current professional activities (transnational wholesale). There are four women and nine men among them. Three other
Chinese men who had arrived in Hungary to pursue university studies married Hungarian women and stayed or later returned and afterwards became involved in activities of the "typical" Chinese migrants of the 1990s. Even if we add them to the thirteen typical cases, less than half of this sample represents the typical majority of Chinese migrants.

There is insufficient information on the genesis of seven relationships. The thirty remaining bonds clearly suggest two main types. Couples of the first group are labelled "student love" relationships. The label "student love" was inspired by the fact that some although not all of the couples in this group had spent study periods together at universities in China, Hungary, or a third country. What all these couples share, however, is their educational status: most of them have completed tertiary education. Sixteen couples fit into this category, with only two cases of separation or divorce, with relationship time spans ranging from five to fifty years with an average of sixteen years, and one or two children per marriage. Three Chinese women in this group had "love" as their main motive of migration.

The other type of relationship characterizes the thirteen "typical" Chinese migrants and is given the working label of "typical Chinese migrant's relationship". These show different scenarios depending on the difference between the social background and the educational status of the two parties. These thirteen relations tend to be much less successful than the "student love" ones: out of the thirteen bonds, eight ended in divorce, while two have been struggling with a serious crisis for years and do not seem to operate smoothly. While in the student love cases of this sample composed of academics, Chinese language professionals, and university graduates in general, at least one (sometimes two) of the members demonstrates advanced skills in her or his partner's mother tongue, the language barrier keeps a distance between typical Chinese migrants and their Hungarian partners.

Finally, there is an unmarried couple with a small child, the mother and the child living separately from the father, in a long-distance relationship. They are in a state of transition and they do not fit either of the two main relationship types mentioned above.

\section{THE INTERVIEWS}

During the current phase of this research seven interviews were made in Hungarian with at least one member of a Chinese-Hungarian mixed couple. Some of the information extracted from the conversations is presented in Table 1. Two interviews had second sessions (\#3 and \#4). Three interviews were conducted in cafés (\#1, \#4, and \#5); two interviewees received me in their homes (\#2 and \#6) and two of 
them at their workplace (\#3, \#7). The group of fourteen people made up by these seven couples included four Chinese women, one of them second generation Chinese, and three Chinese men. The seven cases are very different from each other. Four of the seven couples were formally married.

I tried to obtain basic data about the interviewee and his or her partner and made up a list of open-ended questions to find out about: spoken languages and language strategies in the family; the relationship history; the migration history; data on children and on parenting strategies and practices; data on their everyday life including household division of labour and work activities; relations with Chinese and Hungarian friends and relatives; and a section on how the Chinese and the Hungarians are different, based on their own experiences.

The first interviewee was an eighty-three-yearold Chinese academic (\#1) who met her husband, a scholar himself, at a Beijing university during the 1950s. She moved to Hungary with her husband and first born child in the late 1950s, has lived in Budapest ever since, and has proved to be one of the most fluent Hungarian speakers of all the first generation Chinese persons I met during this research. She had become a widow a couple of years before. The second interviewee, a Hungarian Chinese language professional in her mid-thirties, was engaged in a long-distance "visiting" relationship with a Chinese scientist (\#2) holding a high ranking governmental position in the PRC. They had a small child and she was making great efforts to move to China to live together with the father of her child. The third interviewee, a middle aged Hungarian economist and tai chi practitioner, had divorced his Chinese wife (\#3) several years ago. He described his divorce as damaging both psychologically and financially. The story of the fourth relationship was told by a middle aged Hungarian woman with teenage children (\#4) separated from her Chinese husband, the father of her children. These two cases show large social as well as cultural differences between the Chinese and the Hungarian partners. The fifth interview was made with the active participation of both partners, in this case a Chinese wife and her Hungarian husband (\#5), both in their late thirties. My seventh interviewee, a second generation Chinese woman raised and living in Hungary, dated a young Hungarian man (\#6) and gave special insights into partner selection considerations of second generation Chinese persons in Hungary. The eighth person involved in a mixed relationship was a woman in her mid-thirties having an eight-year long dating affair with a successful transnational entrepreneur in his mid-forties who arrived in Hungary shortly after the shift of regimes.

In spite of deficiencies of unbalanced data, what my interviewees shared with me provides a unique view of several aspects of the life experiences and everyday reality of living in a Chinese-Hungarian mixed relationship in Hungary. No matter how much I would like to avoid producing an ethnically biased, ethnocentric image of this phenomenon, during the course of the research I noticed that marriage is a culturally strongly embedded concept, and it is especially so in Chinese society, as we have seen in the story about the respectable Chinese gentleman and his wife's nephews.

Table 1

Survey chart of the seven interviewed Chinese-Hungarian partner relationships

\begin{tabular}{|c|c|c|c|c|c|c|c|c|c|c|c|c|c|c|}
\hline \multirow[b]{2}{*}{ Gender } & \multicolumn{2}{|c|}{$\begin{array}{c}\text { Couple \#1 } \\
\text { (A-B) }\end{array}$} & \multicolumn{2}{|c|}{$\begin{array}{c}\text { Couple \#2 } \\
\text { (C-D) }\end{array}$} & \multicolumn{2}{|c|}{$\begin{array}{l}\text { Couple \#3 } \\
(E-F)\end{array}$} & \multicolumn{2}{|c|}{$\begin{array}{c}\text { Couple \#4 } \\
(\mathrm{G}-\mathrm{H})\end{array}$} & \multicolumn{2}{|c|}{$\begin{array}{c}\text { Couple \#5 } \\
(I-J)\end{array}$} & \multicolumn{2}{|c|}{$\begin{array}{l}\text { Couple \#6 } \\
(\mathrm{K}-\mathrm{L})\end{array}$} & \multicolumn{2}{|c|}{$\begin{array}{c}\text { Couple \#7 } \\
(M-N)\end{array}$} \\
\hline & $\mathrm{F}$ & $M$ & $\mathrm{~F}$ & $M$ & $\mathrm{~F}$ & $M$ & $\mathrm{~F}$ & $M$ & $\mathrm{~F}$ & $M$ & $\mathrm{~F}$ & $M$ & $\mathrm{~F}$ & $M$ \\
\hline Chinese & yes & no & no & yes & yes & no & no & yes & yes & no & yes & no & no & yes \\
\hline University degree & yes & yes & yes & yes & no & yes & yes & no & yes & yes & yes & yes & no & yes \\
\hline Inter & yes & no & yes & no & no & yes & yes & no & yes & yes & yes & no & yes & no \\
\hline $\begin{array}{l}\text { Registered mar- } \\
\text { riage }\end{array}$ & yes & yes & no & no & yes & yes & yes & yes & yes & yes & no & no & no & no \\
\hline $\begin{array}{l}\text { Divorce, separa- } \\
\text { tion }\end{array}$ & no & no & no & no & yes & yes & yes & yes & no & no & yes & yes & no & no \\
\hline $\begin{array}{l}\text { ence in } \\
\text { ary }\end{array}$ & yes & yes & no & no & no & yes & yes & yes & yes & yes & yes & yes & yes & yes \\
\hline $\begin{array}{l}\text { Children in com- } \\
\text { mon }\end{array}$ & yes & yes & yes & yes & no & no & yes & yes & yes & yes & no & no & no & no \\
\hline $\begin{array}{l}\text { Speaks partner's } \\
\text { language }\end{array}$ & yes & yes & yes & no & yes & no & no & yes & yes & yes & yes & no & no & yes \\
\hline
\end{tabular}


The seven interviews conducted with members of Chinese-Hungarian couples show many differences and involve people coming from very different backgrounds and life situations. The age of my interviewees varies from twenty-eight to eighty-three. There is an elderly Chinese woman who has lived most of her adult life in Hungary attached to her Hungarian family (\#1) and there is a young second generation Chinese woman who has not found a stable partner yet - of any nationality (\#6). There is a young Hungarian woman in a relationship with a Chinese politician dedicated to his career (\#2). There is a Hungarian student majoring in Chinese who married a Chinese girl, a fellow student in Beijing, and started a family with her in Budapest (\#5). Couple \#4 started out from a similar international student situation in a third country, Ethiopia. However, the Chinese husband's professional career makes him a fairly typical example of the Chinese entrepreneur migrant to the Hungary of the 1990s. A different migrant strategy is employed by the woman who arrived in Hungary with her Chinese husband on the way to the US, which she could not eventually reach (\#3). According to her divorced Hungarian husband's account, she fulfilled stereotypical expectations of Asian women, being submissive, silent and accepting. She did not work outside their home and became dependent on her Hungarian husband, with whom she could communicate in a limited way. It has to be borne in mind that the relationship literature suggests that wives and husbands may experience their marriage separately and that sometimes the two versions, "his marriage" and "her marriage" cannot be meaningfully combined into a couple version (Efron Pimentel, 2000, p. 35).

The relationships I inquired about are all in different phases. One marriage $(\# 1)$ ended with the Hungarian partner's death, two (\#3 and \#6) with divorce or separation. The second longest relationship (\#4) has gone through different phases with periods of separation with a possible divorce in sight at the time of the interview. The shortest relationship lasted several months, the longest nearly fifty-eight years.

Transnationality is one of the most extensively discussed aspects of Chinese migrants' lives. Marriages between migrants and members of the host society inevitably create simultaneous social ties to different geographical localities. Although this applies to the Chinese members of the seven couples interviewed so far, successful transnational practices cannot be observed in the lives of spouses and children. Couple \#1 lived most of their lives before the transnational era. The Chinese partner in couple \#2 is tied to China inseparably by work, responsibilities and family relations. Even while in Hungary, the Chinese woman in couple \#3 did not act as a transnational businesswoman, in spite of periodical family visits the couple paid to China. The Chinese tradesman of couple \#4 could be considered an exception. However, he did not teach his children Chinese, and according to an episode of failed family attempt to settle in China related by his wife, he lost the ability to become integrated again in his home country after nearly two and a half decades spent in Europe. Members of couple \#5 cultivate family ties in both countries; their work as translators, however, tie them to Hungary for the time being. A transnational way of life for the children of Chinese-Hungarian mixed marriages is difficult to lead without Chinese language acquisition. Four of the seven couples have children. In two marriages, parents did not teach their children any Chinese (couple \#1 with two adult children; couple \#4 with four children in their late teens and early twenties). Reaching adulthood, the younger daughter of couple \#1 decided to take Chinese as a university career and became a fluent speaker. Couples \#2 and \#5 have children aged from two to eight; these children understand and speak Chinese.

The total time of the seven interviews is twenty-two hours, with the shortest being eighty minutes and the longest seven hours in two sessions. Some of the interviews reached special qualitative depth about relationship histories and personal experiences of lives in Chinese-Hungarian mixed partner relationships. These offer themselves for narrative analysis that is outside the scope of the present paper.

The sociological literature on marriage suggests that homogamous relationships have better chances of being successful over time than heterogamous one. Studies of intermarriage support the view that the greater the cultural difference between the partners, the greater is the risk of relationship failure. There were several cultural issues raised during the conversations that seemed to be at the core of the coexistence with their partners and that prompted very active reactions from the interviewees. These covered values, norms and practices and observations of culturally conditioned behaviour. Hungarian interviewees expressed their preferences for certain Chinese cultural traits and the lack of it for others more explicitly than did my Chinese informants concerning Hungarian values, norms and practices. Some notions appeared in a predominantly negative context (culturally conditioned Chinese emotions, norms and expectations of Chinese family culture, use of socioeconomic resources), some in a markedly positive context (conservative Chinese family values, Chinese work ethic).

\section{Culturally conditioned emotions, culturally conditioned expression of emotions}

Several questions concerned the differences between Chinese and Hungarian notions of love and emotions in general and whether or not there are cultural differences in how they are expressed. The Chinese and 
Hungarian interviewees coincided in expressing that hiding thoughts and emotions is typically Chinese. The elderly Chinese academic (\#1) stated that "the Chinese keep their emotions to themselves" and the young Hungarian mother (\#2) held the view that "the Chinese don't let their emotions show. A Chinese person always hides the thing that is most valuable to him or to her. They wouldn't let it show". In her husband's account his Chinese wife (\#3) was hiding her real self and real emotions from him for years. Another Hungarian mother (\#4) talked about her Chinese husband's sentiments like this: "My husband doesn't show his emotions. They [the Chinese] cannot love the way we think about love. His children also feel that he doesn't love them. And he doesn't understand why they think he doesn't love them".

\section{Family culture}

Norms, expectations and practices related to family culture were discussed in detail in six out of the seven cases. As we have seen in the previous section, studies on Chinese family relations emphasized the importance of parental approval of a marriage and the importance of the respectful relationship maintained with spouses' parents and relatives. Efron Pimentel has shown that the lack of parental approval of a union is strongly related to a lower marriage quality in Beijing marriages (Efron Pimentel, 2000). A couple's relations with Chinese in-laws discussed in various contexts are a central theme in five out of the seven interviews (\#1, \#3, \#4, \#5, and \#6). The way Chinese partners wanted to live up to the Chinese norms of respect and obligation towards their parents, close kin and extended family, and the way the couple subsequently handled relations with Chinese relatives and with each other became a source of recurrent conflict in two of the seven cases described above (\#3, \#4). The Chinese partner's relatives staying with the couple in Hungary for long periods of time or moving to Hungary indefinitely raised serious tensions between the partners. The second generation Chinese woman in her late twenties (\#6), who has distanced herself from the Chinese migrants living in Hungary, her parents included, has made constant references to some of her peers in the Chinese colony living in semi-arranged marriages under constant control (in transnational situations under electronic control via the internet) of parents. The couple with two small children (\#5) make strong efforts so that the Chinese wife's recently retired but relatively young parents could move in with them in Budapest.

\section{Conservative family values}

Coinciding with recent anthropological scholarship, my second generation interviewee (\#6) emphasized that although rapidly changing, conservative family and parenting values still hold in certain segments of Chinese society. While explaining the reasons for their involvement with their Chinese partners and in contrast with the negative view on Chinese family culture, three Hungarian women (\#2, \#4, and \#7) mentioned that their own conservative family backgrounds had a positive role in their partner choice and emphasized their likeness with their partners in this respect.

\section{Use of socioeconomic resources}

The topic of spending and distributing financial resources earned by members of the couple often came up in relation to culturally conditioned responsibilities and duties towards the Chinese partner's close relatives and extended Chinese family back in China. It was a recurrent issue in four interviews with couples (\#2, \#3, \#4, and \#6). According to Kalmijn, a couple's socioeconomic resources produce their economic well-being and status (Kalmijn, 1998). Economic well-being is shared by the family members, and status is granted to the family as a unit rather than to its individual members. As a result, the income and status of one spouse contribute to the income and status of the other by raising the income and status of the family (Kalmijn, 1998). The Hungarian partner of couple \#4 remarked that her Chinese husband's definition of "his family" primarily referred to his parents, siblings and cousins in China and did not coincide with her definition of "her family", the latter referring to their nuclear family composed of the intermarried couple and their children. Disagreement about the use of financial resources was a major source of marital conflict for two couples (\#3 and \#4), leading to a tormented divorce in one case (\#3) and giving an insight into how wealth is accumulated by a Chinese merchant and how money earned in Hungary is distributed along family ties in China (\#4).

\section{Morals and work ethics}

Changing morals and ethics have in all walks of life in China been targeted in recent anthropological scholarship (see for example Stafford, 2013; Kleinman et al., 2011). The issue of the role of Chinese morals and ethics as culture-specific in several areas of life was raised in four interviews (\#2, \#3, \#4, and \#6). Two informants (\#4 and \#6) contrasted Chinese and Hungarian work ethics, showing that of the opposing ethnic group in a less favourable light. In one case (\#2) the Hungarian partner described her Chinese partner's moral standards and life-guiding ethical principles positively and associated them with Chinese ideals of working for the good of the community. The husband who divorced his Chinese wife (\#3) situated his experience in a larger context of 
a "ripping-off marriage industry by Chinese women" that he considers a side-effect of changing morals in contemporary China.

\section{CONCLUSIONS}

The qualitative anthropological research on Chinese-Hungarian inter-ethnic couple relations presented in this paper focuses on a so far unexplored field of Chinese migrants' integration in Hungary. A substantial proportion of Chinese migrant entrepreneurs arrived in Hungary between 1989 and 1992 and formed the largest visible migrant group in Hungary, reaching forty thousand persons by the end of the 1990s. It was assumed that there were very few Chinese-Hungarian inter-ethnic relationships. The data put forward in this study have no statistical relevance for the Chinese migrant population in Hungary; nevertheless, they offer information on the existence of such bonds. What interviewees shared during the field research provides a unique view of several aspects of the life experiences and everyday realities of living in a Chinese-Hungarian mixed relationship.

The paper cannot unquestionably explain the relatively low incidence of this phenomenon. The literature suggests that it might be related to the socially isolated "middleman minority" position of Chinese migrants in Hungary (Nyíri, 2010b), although recent studies on successful transnational Chinese businessmen in Hungary contest this view, stating that they are connected to the host society by various types of social bonds (Várhalmi, 2013).

The sample of thirty-seven couples outlines two characteristically different types of relationships. The first type is referred to as "student love" relationships, and it is characterized by closeness in educational status. The second type is the "relationship of the typical Chinese migrants" with a larger social and educational distance between its members. Relationships in the former group tend to be more successful and persistent in time, with two cases of divorce or separation out of sixteen, whereas the latter are considerably less persistent, with eight cases of divorce or separation and two cases of crises out of thirteen bonds. Another notable finding is that Chinese-Hungarian marriages studied in this research are more persistent in time if the Chinese partner is female.

Articles on changing Chinese family relations have emphasized the relatively persistent and characteristic nature of Chinese family culture (e.g. Efron Pimentel, 2000). The personal accounts of Hungarian partners involved in Chinese-Hungarian mixed relationships have coincided with the literature reflecting on culturally strongly embedded concepts related to marriage and family, and on culturally different notions of love and morals. Conservative values held by some of the Hungarian members coming from the countryside were reported to have found their attractive counterpart in their respective Chinese partners.

\section{ENDNOTES}

1 See for example Dribe and Lundh (2008).

2 This concept is useful during the interpretation of the partner choices of the first generation of $\mathrm{Chi}$ nese migrants. The situation is changing with the bilingual second generation turned young adults by the 2010s whose position in Hungarian society is very different from that of their parents.

3 See for example Emily Martin Ahern's classical monograph on Chinese ritual and politics (Martin Ahern, 1981), or the work of Maurice Freedman, Burton Pasternak, and Myron Cohen.

4 In her anthropological analysis of traditional marriage patterns in a Hong Kong lineage, Watson (1981) connects the affinal relations created by marriage to the reproduction of social class and social inequality.

5 The increased attention on the school has made many mixed-marriage parents adopt a reserved attitude. Also, I have found that men struggling in a problematic relationship are less likely to share their experiences than women regardless of whether they are Chinese or Hungarian.

6 Data from the field suggest that time is also an important factor from the point of view of transnational migrants' possibly changing partner preferences through the course of their lives: several Chinese male migrants pursuing the typical career of commerce chose Chinese partners after the divorce or separation from their Hungarian partners. Time and failed intermarriage experience paired with what Erikson (1997) refers to as cultural generativity may allow migrant individuals (as well as their Hungarian partners) to reconsider their partner choice preferences and make them opt for more homogamous relationships.

This paper was presented previously during $10^{\text {th }}$ International Conference "Woman in Culture: Gender, Culture \& Migration” held at University of Gdansk, Poland, in March 2015. The conference was co-funded from Norway Grants in the Polish-Norwegian Research Programme operated by the National Centre for Research and Development.

This work was supported by project K112282 of OTKA, the Hungarian National Scientific Research Fund.

\section{References}

Basch, L., Glick Schiller, N., \& Szanton Blanc, C. (1994). Nations unbound. Transnational projects, 
postcolonial predicaments and deterritorialized nation-states. Amsterdam: Gordon and Breach Science Publishers.

Bélanger, D., \& Tran, G. L. (2011) The impact of transnational migration on gender and marriage in sending communities of Vietnam. Current Sociology, 59, 59-77.

Chua, A. (2011). Battle hymn of the tiger mother. UK: Penguin Books.

Chua, A. (2014). The triple package: how three unlikely traits explain the rise of fall of cultural groups in America. UK: Penguin Books.

Davin, D. (1976). Woman-work: women and the Party in revolutionary China. Oxford: Clarendon Press.

Davin, D. (1999). Internal migration in contemporary China. New York: St. Martin's Press.

Davin, D. (1988). Book review on Domenach Jean-Luc, Chang-Ming Hua (1987). Le marriage en Chine. Paris: Presses de la Fondation des Scinces Politiques, 187 p. The China Quarterly, 113, 119-120.

Dribe, M., \& Lundh, C. (2008). Intermarriage and immigrant integration in Sweden: An exploratory analysis. Acta Sociologica, 51, 329-354.

Efron Pimentel, E. (2000). Just how do I love Thee?: Marital relations in urban China. Journal of Marriage and Family, 62, 32-47.

Erikson, E. H. (1997). The life cycle completed. Extended version with New Chapters on the Ninth Stage of Development by Joan H. Erikson. New York: W. W. Norton.

Gaspar, S. (2011). Comparing EU bi-national partnerships in Spain and Italy 1. Sociologia On Line, 2, 101-119 (Retrieved from Research Gate on 10 August 2015).

Hohmann-Marriott, B. E., \& Amato, P. (2008). Relationship quality in inter-ethnic marriages and cohabitations. Social Forces, 87, 825-855.

Kalmijn, M. (1998). Intermarriage and homogamy: Causes, patterns, trends. Annual Review of Sociology, 24, 395-421.

Kalmijn, M., de Graaf, P., \& Janssen, J. (2005) Intermarriage and the risk of divorce in the Netherlands: The effects of differences in religion and in nationality, 1974-94. Population Studies, 59, 71-85.

Kalmijn, M., \& van Tubergen, F. (2010). A comparative perspective on intermarriage: Explaining differences among national-origin groups in the United States. Demography, 47, 459-479.

Kleinman, A., Yan, Y., Jun, J., Lee, S., \& Zhang, E. (2011). Deep China. The moral life of the person. What anthropology and psychiatry can tell us about China today. Berkely: University of California Press.

Kováts, A. (2014). Migrációs helyzetkép Magyarországon [Migration overview of Hungary]. In: I. Tarrósy, V. Glied, \& Z. Vörös Zoltán (eds.), Migrációs tendenciák napjainkban [Contemporary trends of migration] (pp. 329-345). Pécs: Publikon Kiadó.

Kwok-bun, C. (ed.). (2013). International Handbook of Chinese Families. Springer: New York.

Martin Ahern, E. (1981). Chinese ritual and politics. Cambridge: Cambridge University Press.

Nyíri, P. (2006). Kínaiak és afgánok Magyarországon: két migráns csoport érvényesülési stratégiái [Chinese and Afghans in Hungary: immigrant strategies of two migrant groups]. In: M. Feischmidt, \& P. Nyíri (eds.), Nem kívánt gyerekek? Külföldi Gyerekek magyar iskolákban [Unwanted children? Foreign children in Hungarian schools] (pp. 39-74). Budapest: MTA Nemzeti-Etnikai Kisebbségkutató Intézet - Nemzetközi Migrációs és Menekültügyi Kutatóközpont

Nyíri, P. (2010a). Egy transznacionális "közvetíto" kisebbség”: kínai vállalkozók Magyarországon [A transnational middleman minority: Chinese entrepreneurs in Hungary]. In: M. Feischmidt (ed.), Etnicitás. Különbségteremtő társadalom [Ethnicity. Society marking the difference] (pp. 141-151). Budapest: Gondolat-MTA Kisebbségkutató Intézet. Nyíri, P. (2010b). Kínai migránsok Magyarországon: Mai tudásunk és aktuális kérdések [Chinese migrants in Hungary. What we know today and relevant issues]. In: A. Hárs, \& J. Tóth (eds.), Változó migráció - változó környezet [Changing migration in a changing context] (pp. 147-171). Budapest: MTA ENKI.

Stafford, C. (ed.). (2013). Ordinary ethics in China. London School of Economics Monographs on Social Anthropology. Volume 79. London: Bloomsbury.

Várhalmi, Z. (2013). Vállalkozó migránsok Magyarországon [Migrant entrepreneurs in Hungary]. In: A. Kováts (ed.), Bevándorlás és integráció. Magyarországi adatok, európai indikátorok [Immigration and integration. Hungarian data, European indicators] (pp. 89-100). Budapest: Centre for Social Sciences, Hungarian Academy of Sciences.

Watson, R. S. (1981). Class differences and affinal relations in South China. Man, New Series, 16, 593615.

Worner, S. (2010). Inter-ethnic marriage and partner satisfaction. Ruhr Economic Papers \#221. 